49 Waring GO III, Lynn MJ, Strahlman ER, Kutner MH, Culbertson W, Laibson $\mathrm{P}$, et al. Stability of refraction during four years after radial keratotomy in the prospective evaluation of radial keratotomy study. Am f Ophthalmol 1991;111:133-44.

50 Krauss JM, Puliafito CA, Steinert RF. Laser interactions with the cornea. Sure Ophthalmol 1986;1:37-53.

51 Seiler T, Wollensak J. Myopic photorefractive keratectomy with the excimer laser. One year follow-up. Ophthalmology 1991;98:1156-63.

52 McDonald MB, Liu JC, Byrd TJ, Abdelmegeed M, Andrade HA, Klyce SD, et al. Central photorefractive keratectomy for myopia. Partially sighted and normally sighted eyes. Ophthalmology 1991;98:1327-37.

53 Seiler T. Laser corneal surgerv. In: Waring GO III, ed. Refractive keratotomy for myopia and astigmatism. St Louis: Mosby Year Book, 1992.

54 McDonald MB, Frantz JM, Klyce SD, Salmeron B, Beuerman RW, Munnerlyn $C R$, et al One-year refractive results of central photorefractive keratectomy for myopia in the nonhuman primate cornea. Arch Ophthalmol keratectomy for $1990 ; 108: 40-7$.

55 Fantes FE, Hanna KH, Waring GO III, Pouliquen Y, Thompson KP, Savoldelli $M$. Wound healing after excimer laser keratomileusis (photoSavoldelli $M$. Wound healing after excimer laser keratomileusis (photo
refractive keratectomy) in monkeys. Arch Ophthalmol 1990;108:665-75.

56 Hanna KD, Pouliquen Y, Waring GO III, Savoldelli M, Cotter J, Morton K, et al. Corneal stromal healing in rabbits after $193 \mathrm{~nm}$ excimer laser surface ablation. Arch Ophthalmol 1989;107:895-901

57 Tuft SJ, Zabel RW, Marshall J. Corneal repair following keratectomy. Invest Ophthalmol Vis Sci 1989;30: 1769-77.

58 Strampelli B. Sopportabilita di linti acriliche in camera anteriore nella afachia e nei vizi di refrazione. Amnali di Ottamologia e Clinica Oculistica 1954;80: $75-82$.

59 Barroquer J. Anterior plastic lenses. Results of and conclusions from five year experience. Trans Ophthalmol Soc UK 1959;79:393-42

60 Waring GO III. Phakic intraocular lenses for the correction of myopia - where do we go from here? Refractive and Comeal Surgery 1991;7:275-6.

61 Baikoff G, Joly P. Comparison of minus power anterior chamber lenses and myopic epikeratoplasty in phakic eyes. Refractive and Corneal Surgery 1990;6:252-60

62 Worst JGF, Veen GVD, Los LI. Refractive surgery for high myopia. The Worst-Fechner biconcave iris claw lens. Doc Ophthalmol 1990;75:335-4

63 Mimouni F, Colin J, Koffi V, Bonnet P. Damage to the corneal endothelium from anterior chamber intraocular lenses in phakic myopic eyes. Refract Comeal Surg 1991;7:277-81.

64 Kovalevskii EI, Dubovskaia LA, Kotiasheva GI, Sotnikova TA, Mishustin $\mathrm{AV}$. The surgical prophylaxis stage in the progression of myopia in children. Oftalmol Zh 1989;4:199-202

65 Svirin AV, Antipova OA, Milovanova ZP. Collagen plastic surgery in progressive myopia. Vestn Oftalmol 1989;105:20-5.

66 Alberth B, Nagy Z, Berta A. Combined surgical procedure for the prevention of blindness caused by progressive high myopia. Acta Chir Hung 1988;29: $3-13$

67 Golychev VN, Morozova IV. A combination of scleroplasty with intrascleral revascularization in myopia. Oftalmol $Z h$ 1989;3:160-2.

68 Tarutta EP, Shamkhalova ES, Valskii VV. An analysis of the late results of scleroplasty in progressive myopia. Oftalmol $Z h$ 1989;4:204-7.

(Accepted 20 May 1992)

\title{
US health care. I: The access problem
}

\section{Jennifer Dixon}

The crisis in health care is looming large in the presidential campaign in the United States, which is now approaching its climax. This is the first of three articles analysing the profound problems and proposed solutions
Health Services

Research Unit, London School of Hygiene and Tropical Medicine, London WC1E 7HT Jennifer Dixon, honorary lecturer in public health medicine

BMF 1992;305:817-9
The "issue from hell" and the "lose-lose issue" are how health care in the United States has been described over the past year. After two decades of crisis the American health system represents a policy problem which, despite much impressive analysis, refuses to be solved. The twin problems of increasing costs and decreasing access have prompted a myriad of proposals for health care reform to which President Bush recently added his own. But its staying power as a domestic problem reflects the fact that reform of American health care is a complex political issue, not simply a technical one. This year's presidential election provides an opportunity for politicians to come up with a reform strategy which offers more than the "look concerned but do nothing" policy of the current administration.

This series of three articles examines why reform is necessary and what form it should take. Part I examines access to health care and changes over recent years. Part II considers the costs of American health care and the impact of key cost containment strategies. Part III looks at the proposals on offer and the likely course of health care reform.

\section{Access}

It is a stark fact that access to health care in the United States is rationed by ability to pay. In 1990, although $83 \%$ of all non-elderly Americans (those under 65) were covered by some form of health insurance, some $16.6 \%$-that is, 35.7 million peoplehad none at all (see table I). ${ }^{1}$ Though uninsured people face the most difficulty obtaining care, access is a growing problem for all Americans. This paper exmines why access is such a concern for three groupsnamely, people without health insurance, those with public insurance through the Medicare and Medicaid programmes, and those covered by private health insurance. The paper also examines federal initiatives to expand access.

\section{Uninsured people}

Without insurance to cushion the costs of care uninsured people face steep bills for health services. As
TABLE 1-Non-elderly and elderly Americans with selected sources of health insurance coverage in 1990

\begin{tabular}{|c|c|c|}
\hline Source of coverage & $\begin{array}{c}\text { Non-elderly } \\
\text { No (millions) } \\
(\%)\end{array}$ & $\begin{array}{c}\text { Elderly } \\
\text { No (millions) } \\
(\%)\end{array}$ \\
\hline Total population & $215.9(100)$ & $30 \cdot 1(100)$ \\
\hline Total with private health insurance & $158 \cdot 3(73)$ & $20 \cdot 6(68)$ \\
\hline Employer coverage & $138.7(64)$ & $10 \cdot 0(33)$ \\
\hline Other private coverage & $19 \cdot 7 \quad(9)$ & $10 \cdot 6 \quad(35)$ \\
\hline Total with public health insurance & $29 \cdot 2$ (14) & $28.9(96)$ \\
\hline Medicare & $3.5 \quad(2)$ & $28 \cdot 8(96)$ \\
\hline Medicaid & $21 \cdot 6(10)$ & $2 \cdot 6 \quad(9)$ \\
\hline CHAMPUS/CHAMPVA* & $5.9 \quad(3)$ & $1 \cdot 1 \quad$ (4) \\
\hline No health insurance & $35 \cdot 7$ (17) & $0 \cdot 3 \quad(1)$ \\
\hline
\end{tabular}

Source: Employee Benefit Research Institute.'

Figures may not add to totals because individuals may receive coverage from more than one source.

${ }^{\star}$ Includes Civilian Health and Medical Program for the Uniformed Service and Civilian Health and Medical Program for the Department of Veterans' Affairs.

a result they delay or avoid seeking care ${ }^{2}$ and tend to use a patchy network of health services that are free or cheap-mainly hospital emergency rooms, outpatient clinics, and publicly funded health centres. However, in recent years hospital emergency rooms have become more crowded ${ }^{3}$ and public health centres have become scarcer, ${ }^{45}$ as have the primary care physicians to work in them. ${ }^{\circ}$ Since hospitals and physicians must foot the bill when uninsured people can't or won't pay for their health care, providers have taken steps to reduce their financial risk. Some hospitals have cut back on services uninsured patients use the most (such as emergency room, outpatient, and obstetric care) or relocated out of neighbourhoods where they tend to seek care. Outside hospitals private physicians can and do refuse to treat uninsured people rather than risk picking up the bill. The lack of access to even basic preventive care has contributed to the current epidemic of preventable childhood infectious disease ${ }^{8}$ and the high infant mortality that persists in the United States. ${ }^{9}$

Not surprisingly, Americans with no health insurance use fewer health services than Americans who have insurance. Studies show that uninsured people receive less ambulatory and inpatient care, ${ }^{1011}$ and utilisation differences persist even after adjusting for race, geographic location, and health status. ${ }^{12}$ Once 
TABLE II-Proportion of people uninsured among workers aged 18-64 by industry group 1990

\begin{tabular}{lr}
\hline & $\%$ \\
\hline Total & 16 \\
Self employed & 22 \\
Government & 7 \\
Agriculture & 39 \\
Construction & 31 \\
Retail trade & 24 \\
Services & 17 \\
Other industries $^{\star}$ & 11 \\
\hline
\end{tabular}

Source: Employee Benefit Research Institute

*Include mining, transportation, communications, utilities, finance, real estate, manufacturing, and wholesale trade. in hospital uninsured patients are treated differently ${ }^{13}$ and inpatient mortality has been shown to be greater. ${ }^{14}$

As access to care decreases, the number of uninsured people increases. In 1988, 33.6 million Americans $(15.9 \%$ of the non-elderly population) were uninsured compared with 34.4 million (16.1\%) in 1989 and 35.7 million $(16.6 \%)$ in 1990 (table I).' In addition to the $16.6 \%$ of non-elderly Americans who were uninsured during all of 1990 , roughly a quarter of the rest would have been uninsured for shorter periods ${ }^{15}$ and still more would have been underinsured.

Annual surveys such as the current population survey paint a consistent picture of uninsured people. In 1990 more than half were working, mostly in smal businesses and in industries such as agriculture, construction, and retailing (table II). Two thirds are in households where the income is greater than a federally defined poverty level (almost $\$ 14000$ for a family of four in 1992), and as a consequence they are not poor enough to qualify for Medicaid (the publicly financed programme for the poor). Lack of insurance is more prevalent among Hispanic and black people, among men, in the southern states, and in rural areas. In 1990 almost one third of uninsured people were aged between 18 and 24 and $15 \%$ were under 18 .

Concern is rising not only because uninsured people are more numerous but because a growing proportion are working middle class Americans whose employers no longer offer insurance. Uninsured people are now a significant economic problem $^{16}$ as well as a moral and political one. As the editor of $\mathcal{Y} A M A$ recently observed, "a long term crying need has developed into a national moral imperative and now into a pragmatic necessity as well." ${ }_{17}$

\section{Medicaid and access}

Around $14 \%$ of non-elderly Americans have some form of publicly funded health insurance. ${ }^{1}$ In most cases this is Medicaid, which is a health programme for the poor. Medicaid covers poor families with dependent children and long term nursing home care to low income elderly and disabled people. States can set their own eligibility rules for Medicaid and therefore control the number of people who are enrolled. In the early 1980 s these rules became tougher. ${ }^{18}$ As a result poor families had to be poorer to qualify, and many of those disqualified added to the ranks of the uninsured. ${ }^{19}$

Concerned by the number of uninsured children, in the late 1980s congress passed laws which extended Medicaid to cover more uninsured pregnant women and children. These laws act incrementally and aim to provide Medicaid cover to everyone in poverty aged 18 and under by just after the turn of the century. Congress also granted transitional Medicaid cover for the unemployed who start a new job. Partly due to the expansions the number of people enrolled with Medicaid jumped from 18.5 million in 1989 to 21.6 million in $1990{ }^{\prime}$ but this increase was not large enough to reduce the rise in the number of uninsured people.

Once on Medicaid, individuals are entitled to a range of health care benefits. Federal laws spell out which services are available to recipients that states cannot skimp on without federal approval. Benefits are generous and include inpatient, outpatient, and physicians' services-prompting facetious reference to the Medicaid card as the "gold card" to accessing care. However, the states set the reimbursement rates payable to providers for services to Medicaid recipients. These rates are usually much lower than the rates offered by private insurers and other public programmes such as Medicare. For example, the Medicaid reimbursement rate for a total hysterectomy in New York state was $\$ 240$ in 1989 whereas the Medicare rate was $\$ 1448$. 20 Unsurprisingly, this has led to low provider participation in Medicaid in most $\operatorname{states}^{21}$ and decreased the quality of care available..$^{22}$ Signs in private physicians' offices saying "No Medicaid here" are not uncommon, and Medicaid patients often end up using a similar uncoordinated array of providers as uninsured people.

Nevertheless, Medicaid has gone some way to achieving one of its initial purposes-to increase the access of poor people to medical care. Medicaid services are free to recipients, who use health services at a similar or greater rate to those who are not poor, even after adjusting for health status. ${ }^{12}$ If the other initial purpose of Medicaid-to provide medical care in the mainstream of American medicine ${ }^{23}$ - has not been realised recent legislation encouraging states to enrol Medicaid recipients into health maintenance organisations may improve this.

\section{Medicare and access}

Virtually all elderly (age over 65) Americans have some form of public or private health insurance (table I). Some $96^{1}{ }^{1}$ are covered by Medicare, which is available to elderly people regardless of income or wealth. Apart from age, eligibility for Medicare is linked to the level of social insurance payments made during a person's working lifetime, and only a minority of elderly people do not qualify. Most of these are covered by other public or private insurance, but $1 \%$ of elderly people remain uninsured. ${ }^{\prime}$ Medicare also covers a small proportion of non-elderly disabled people. The Medicare programme is administered and financed by federal government, which determines eligibility, the reimbursement rates paid to providers, and the benefits that are offered. Compared with Medicaid, Medicare funding was protected during the $1980 \mathrm{~s}^{24}$ As a result the numbers enrolled increased and stood at almost 30 million in 1990.

Medicare is as near as the United States gets to a universal comprehensive programme for any section of the population. Like Medicaid, Medicare offers a wide range of benefits, including inpatient, outpatient, and physicians' services. But, unlike Medicaid recipients or uninsured people, the elderly on Medicare enjoy greater access to care. Providers are more willing to offer services to Medicare beneficiaries, partly because the large size of the elderly population means significant income for providers and partly because Medicare reimbursement rates are more generous than Medicaid.

But there remain important access problems. This is because Medicare does not provide free care: elderly people must contribute towards the costs of the services they use. Out of pocket payments are required for care inside and outside hospital and can be steep. Medicare reimbursement rates for physicians' services are often less than the bill charged by physicians, leaving elderly patients to pay the difference. Also Medicare does not cover some essential services at all-most notably, long term care and prescription drugs - for which the elderly must pay. To plug the gaps left by Medicare two thirds of the elderly population take out private insurance-so called "medigap" insurance. Despite this, elderly people with low incomes use fewer of the services where they are liable to pay more, such as physicians' services or nursing home care..$^{25}$ Since roughly a quarter of elderly people are poor or near to being poor and the costs of care are rising, the differences in use of health services between low income and high income elderly people who depend on Medicare will merit scrutiny in future.

Congress has tried to improve access to care for the elderly. In 1988 the Medicare Catastrophic Coverage Act was passed, which lowered the payments elderly people had to make for hospital care, added cover for 


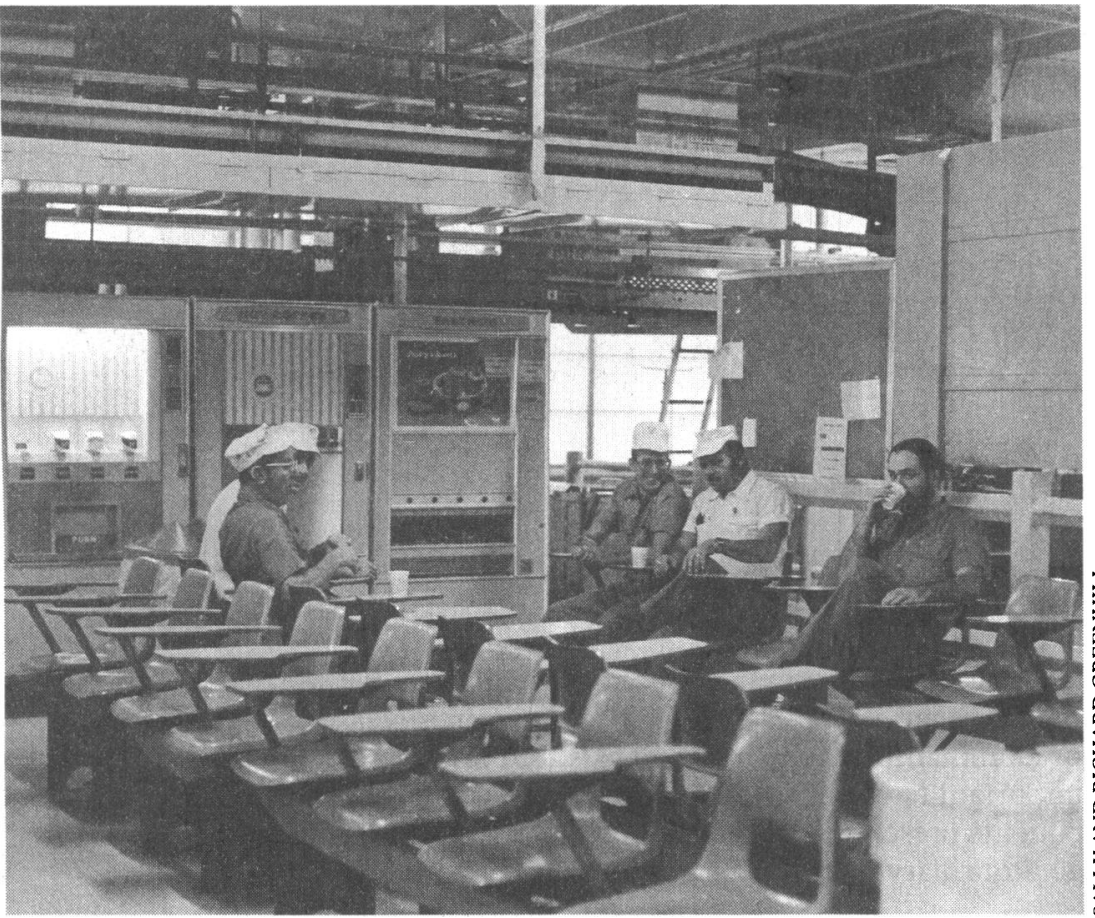

Businesses that can no longer afford health insurance are responsible for rising numbers of uninsured workers

prescription drugs, and made it easier to obtain nursing home and hospice care. However, the law required that the increased access would be financed by the elderly themselves through an extra tax on income. Many elderly groups lobbied hard against the extra tax and the law was eventually repealed.

\section{Privately insured groups}

Almost three quarters of all Americans have some form of private health insurance cover mostly obtained through their workplace or the workplace of a family member. Though businesses foot most of the insurance bill, employees contribute to the cost of the premium and are liable for out of pocket payments for the health services they use. But as costs have risen, the employer based system of health insurance is under strain. More and more businesses (particularly small businesses) do not offer health insurance due to cost, ${ }^{26}$ a policy which is the main reason for the rising numbers of uninsured people. Consequently, between 1980 and 1988, though the number of Americans in employment grew by 15 million, the number covered by private insurance fell by 5 million. ${ }^{27}$ Faced with rapidly rising premium costs, other employers have tried to limit optional health benefits to workers and their dependants ${ }^{28}$ and require employees to pay more. Some businesses are bypassing third party insurance altogether and deciding for themselves which benefits they will offer employees. For example, Rockwell-a multinational corporation providing health benefits to 350000 Americansdecided to eliminate coverage of in vitro fertilisation services for economic reasons. ${ }^{29}$

To keep costs down other employers offer health insurance policies which exclude cover for pre-existing medical conditions such as diabetes and cancer. ${ }^{30}$ Increasingly this means that employees are reluctant to change employers for fear that treatment of a chronic illness will not be covered in the insurance policy offered with a new job. Such employees are effectively locked into their existing employment, a situation which has reached Hollywood executives and molecular biologists ${ }^{31}$ as well as blue collar workers. A contributing factor to "joblock" has been the fear of requiring costly health care during the initial period of new employment (usually one month) before the new insurance policy begins. Interlinked is the widespread problem of underinsurance, particularly for care of chronic diseases and catastrophic and long term care. ${ }^{32}$ Generous media coverage of middle class Americans who have been almost bankrupted by health care costs due to gaps in coverage has fuelled the pervasive anxiety about access.

\section{Conclusion}

The United States health care system leaves over 36 million Americans out in the cold. While the number of people without health insurance rises, the capacity and willingness of the health system to absorb their needs are decreasing. Federal action has concentrated on expanding Medicaid benefits to more of the poor groups. But access is also an increasing concern among middle class groups, who traditionally were well served by the existing system. Access to care is falling because the costs of care are rising.

In next week's issue we shall examine the cost problem and its effect on access.

Much of this study was carried out in the United States in 1990-1 while I was in tenure of a Harkness fellowship.

1 Employee Benefit Research Institute. Sources of health insurance and characteristics of the uninsured. Analysis of March 1991 current population survey. Washington, DC: EBRI, 1992. (Issue brief No 123.)

2 Billings J, Teicholz N. Uninsured patients in District of Columbia hospitals. Health Aff 1990;9:158-65.

3 Rosenthal E. Health problems of inner city poor reach crisis point. New York Times 1990 Dec 24:A1, A9.

4 Martin D. Economic ills: poor are sicker, clinic is poorer. New York Times 199 March 6:B1

5 Brozen N. Poor are rocked by closing of gynecological clinics. New York Times 1991 March 25:B1.

6 Colwill JM. Where have all the primary care applicants gone? $N$ Engl $f$ Med 1992;326:387-93.

7 Feder J, Hadley J, Mullner R. Falling through the cracks: poverty, insurance coverage, and hospitals' care to the poor 1980 and 1982. In: Hospitals and the uninsured poor. New York: United Hospital Fund of New York, 1985:3-30.

8 Hilts PJ. Panel ties measles epidemic to breakdown in health system. New York Times 1991 Jan 9:A17.

9 Schlesinger $\mathrm{M}$, Kronebusch $\mathrm{K}$. The failure of prenatal care policy for the poor. Health Aff 1990;9:91-111.

10 Davies K, Rowland D. Uninsured and underserved: inequities in health care in the United States. Milbank Memorial Fund Quarterly; Health and Society 1983;61:149-76.

11 Weissman J, Epstein AM. Case mix and resource utilisation by uninsured hospital patients in the Boston metropolitan area. JAMA 1989;261:3572-6.

12 Davies K. Inequality and access to health care. Milbank 1991;69:253-73.

13 Braveman PA, Egerter S, Bennett T, Showstack J. Differences in hospital resource allocation among sick newborns according to insurance coverage. IAMA 1991;266:3300-8.

14 Hadley J, Steinberg EP, Feder J. Comparison of uninsured and privately insured hospital patients: condition on admission, resource use, and outcome. ЭAMA 1991;265:374-9.

15 Friedman E. The uninsured. From dilemma to crisis. JAMA 1991;265: 2491-5

16 Dixon J. US health care. II: The cost problem. $B M \mathcal{H}$ (in press).

17 Lundberg GD. National health care reform. An aura of inevitability is upon us. ҰAMA 1991;265:2566-7.

18 Burwell BO, Rymer MP. Trends in Medicaid eligibility 1975-85. Health Aff 1987;6:30-45.

19 Rowland D, Lyons B, Edwards J. Medicaid: health care for the poor in the Reagan era. Annu Rev Public Health 1988;9:427-50.

20 Schwartz A, Colby DC, Reisinger AL. Variation in Medicaid physician fees. Health Aff 1991;10:131-9.

21 Pear R. Low Medicaid fees seen as depriving the poor of care. New York Times 1991 April 2:A1, A14

22 Little Hoover Commission. A prescription for Medi-Cal. Sacramento, California: LHC, 1990.

23 Marmor TR, Morone JA. The health programs of the Kennedy-Johnson years: an overview. In: Warner DC, ed. Towards new human rights: the social policies of the Kennedy-fohnson administrations. Austin, Texas: University of Texas at Austin, 1977:157-82

24 Feder J. Health care of the disadvantaged: the elderly. 9 Health Polit Policy Law 1990;15:259-69.

25 Goodwin EJ, Zeitel LV, Fox KS. Access to health care: Medicare and the poor elderly. In: Povery and health in New York City. New York: United Hospital

26 General Accounting Office. Health insurance: an overview of the working uninsured. Washington, DC: GAO, 1989.

27 General Accounting Office. Private health insurance. Problems caused by a segemented market. Washington, DC: GAO, 1991.

28 Congressional Research Service. Health insurance and the uninsured. Washington, DC: Library of Congress, 1988

29 Kramon G. Rockwell's point man in the health care campaign. New York Times 1991 April 7:F5

30 Cotton P. Pre-existing conditions "hold Americans hostage" to employers and insurance. IAMA 1991;265:2451-3.

31 Lewin T. High medical costs hurt growing numbers in US. New York Times 1991 April 20:A1.

32 Bodenheimer T. Underinsurance in America. N Engl f Med 1992;327:274-7. 